い辺の側面は(101)面, 短い辺の側面は (100) 面である。 結晶には，らせん生長がしばしば見られる。電子線回折 から分子軸注結晶平面に垂直であり，分子鎖は折りたた まれている。カーボン支持膜上で乾燥した単結晶には上 に凸のひだが多く見られる。ひだは結晶の端に多く， (301)面にほぼ平行である。PVA 濃厚水溶液上で, ゆっ くり乾燥した単結晶のレプリカから, PVA 単結晶は上 下に鋭く折れ波状を呈した板状晶であることを認めた。

付記: 終始, ご指導をいただたた当社研究所長松 本昌一博士に心より謝意を表する。また, 実験に協力 された篗津 彰, 神崎春義両氏に感謝する。なお, 本 研究は第19回日本電子顕微鏡学会 (1963年5月), およ び第13回高分子討論会 (1964年11月)で発表した。

\section{文献}

1) A. Keller: Phil. Mag., 2, 1171 (1957)
2) P. H. Geil: J. Polymer Sci., 44, 449 (1960)

3) D. H. Reneker, P. H. Geil: J. Appl. Phys., 31, 1916 (1960)

4）平林 清：桜田編「ポリビニルアルコール」, 199 (1955) 高分子学会

5）坪井 清, 望月隆仁, 松本昌一：第19回日本電子 顕微鏡学会 (1963)

6) K. Tsuboi, T. Mochizuki: J. Polymer Sci., B1, 531 (1963)

7) 平井西夫, 物延一男, 末房 清: 高分子学会第 12 回年次大会 (1963)

8) 平井西夫, 物延一男, 藤原裕男, 山下祐彦: 第 3 回ポリビニルアルコール討論会 (1963)

9）物延一男, 藤原裕男: 高化, 21, 179 (1964)

10) D. C. Bassett, F. C. Frank, A. Keller: Proc. Eur. Reg. Conf. on Electron Microscopy, Delft (1960)

\title{
Studies on Single Crystals of Polyvinyl Alcohol \\ I. Single Crystals of Polyvinyl Alcohol
}

\author{
By Kiyoshi Tsuboi* and Takani Mochizuki*
}

\begin{abstract}
Single crystals of polyvinyl alcohol (PVA) were prepared by isothermal crystallization from $0.3 \%$ solution in triethylene glycol. Single crystals of PVA are parallelogrammic in shape. In many cases the ratio of the length of the longer side to the shorter side is fairly constant and is about 5. The lamella thickness estimated from the length of the shadow is $100 \sim 150 \AA$. The acute angle of the parallelogram is about $55^{\circ}$. The spiral growths are often observed. The granular part is seen at the middle of the lamella and has a similar figure to the external form. Single crystals in triethylene glycol suspension were placed on the surface of a concentrated aqueous solution of PVA, which was allowed to solidify in a few days. The crystals were examined by replica technique. Observations show that PVA single crystals are corrugated platelets in solution. Electron diffraction shows that the chain axes are normal to the lamellae. The molecules must fold back and forth in some way through the platelet. The longer side of the parallelogram corresponds to the (101) plane and the shorter side to the (100) plane. The corrugations are almost parallel to the (301) plane.
\end{abstract}

\section{第 2 報ポリビニルアルコールの双晶}

(1966 年 1 月 14 日受理)

\section{坪井 清*. 望月隆仁*}

\begin{abstract}
要 旨 希薄溶液から作製したボリビニルアルコール(PVA) 単結晶の中には，平行四辺形とは 異なった形の結晶がしばしば見られる。ラス型，半ラス型，Y型，および 2 種類のL型の計 5 種類 の双晶の存在を認めた。電子線回折および結晶形態から, ラス型,および半ラス型双晶では (101) 面, Y 型双晶では(100)面と(001)面, 開き角約 $110^{\circ}$ の L 型双晶では(100)面, 開き角約 $140^{\circ}$ の L 型 双晶では (101) 面が双晶面であることがわかった。PVAの双晶では対称面が結晶の中心にある場合 が多く，結晶の核形成時に双晶が発生しやすいことを示している。
\end{abstract}

* Research Laboratory, Kurashiki Rayon Co., Ltd. (Kurashiki, Okayama)

* 合敷レイヨン株式会社研究所（岡山県倉教市酒津1621） 


\section{1. 緒言}

さきに,ポリビニルアルニール (PVA) の単結晶の基 本型は平行四辺形の板状晶であり, 長い辺と短い辺の長 さの比は約 5 であることを報告した1),2)。希薄溶液から 作製した PVAの結晶の中には，この基本型とは異なっ た形のいわゆる双晶と考えられる結晶がしばしば観察さ れる。双晶に関する観察は PVAの特性や単結晶の結晶 化機構を考える上に参考となろう。高分子物質の双晶は ポリエチレン3),4) やアミロース5，6)に見られるが，その ほかには観察された例が少ない。著者らは, PVAの成 長双晶の形態および双晶面を電子顕微鏡観察および電子. 線回折によって研究した。

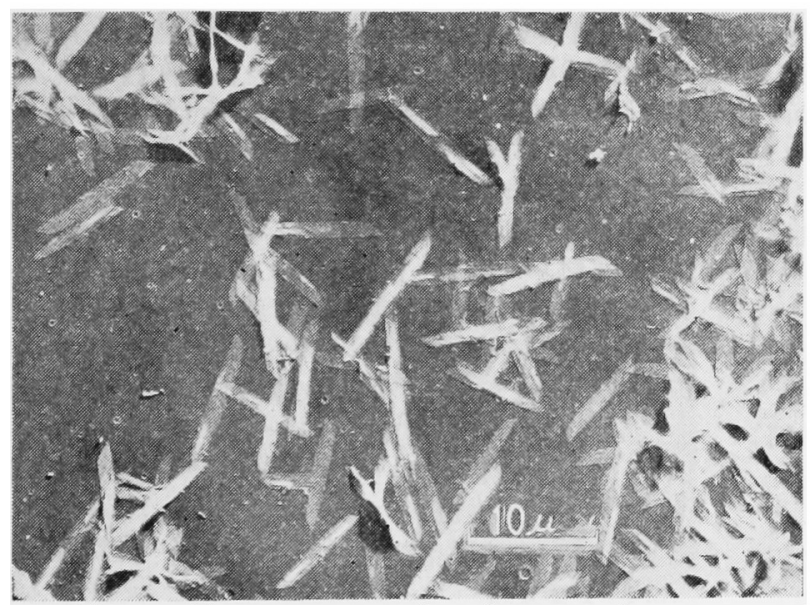

Fig. 1. Electron micrograph at low magnification of single crystals and twins of PVA.

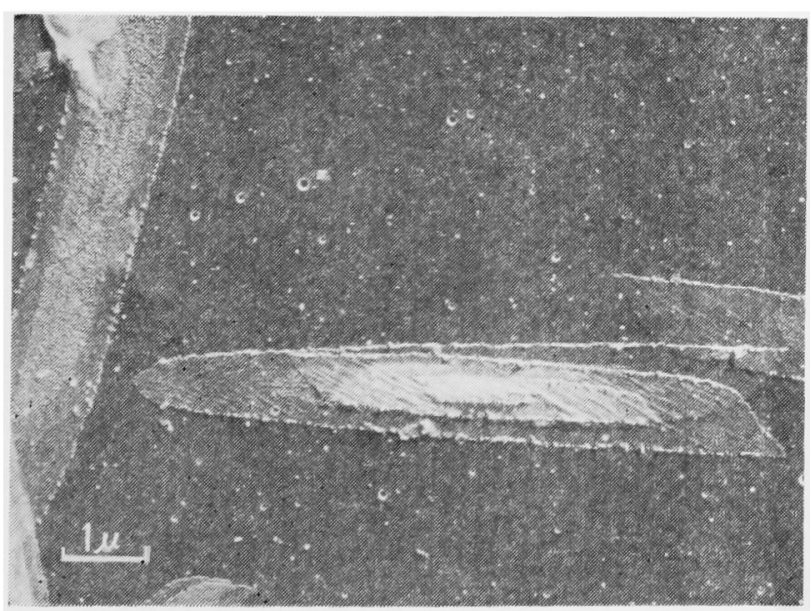

Fig. 2. Electron micrograph of a lath-shaped twin of PVA.
2. 実験

\section{1 単結晶の作製}

重合度約 1700 の PVA t リコールに溶解し， $0.3 \%$ の溶液とし， $195^{\circ} \mathrm{C}$ の恒温才 イルハラスに浸漬して結晶化させた。

\section{2 電子顕微鏡による双晶の観察}

単結晶の奬濁液をカーボン支持膜上にとり，60 $\mathrm{C} て ゙$ 真空乾燥した後，パラジウムのシャドーを施した。平行 四辺形の単結晶に混在する平行四辺形から背違する形の 結晶に注目し，電子顕微鏡観察打よび電子線回折を行な った。

\section{3. 結果と考察}

\section{1 双晶の種類}

Fig. 1 法 PVA 単結晶の低倍率の電子顕微鏡写 真である。ほとんどの結晶は平行四辺形の板状晶 である。平行四辺形の長い辺は $8 \sim 10 \mu$, 短い辺 は 1.5 2 $\mu$ である。多くの平行四辺形の単結晶に

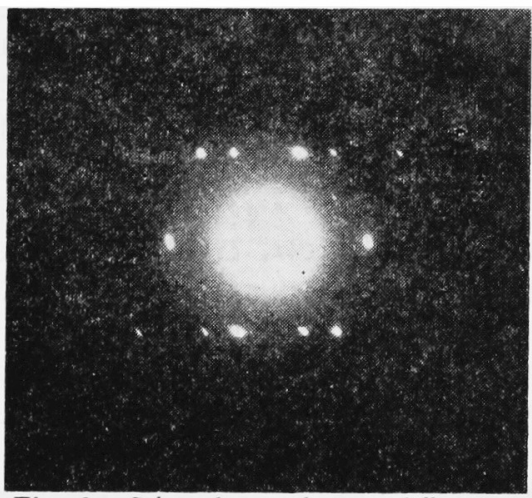

Fig. 3. Selected-area electron diffraction pattern from a lath-shaped twin of PVA.

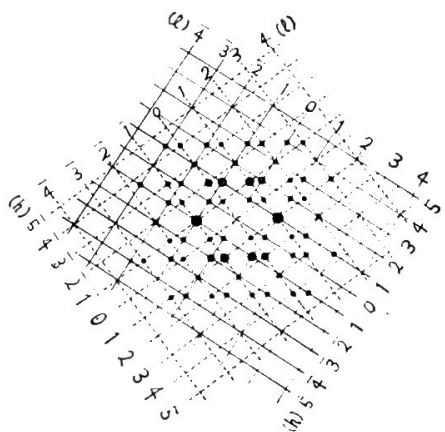

Dots represent the observed reflections.

Fig. 4. The relation of reflections and reciprocal lattice diagrams. 
混在して, ラス型双晶, 半ラス型双晶, Y 型双晶, および L型双晶が観祭さ机る。Fig. 1 に注見られないが，Fig. 11 および 12 で示すように，L型双晶には開き角が $110^{\circ}$ と $140^{\circ} の 2$ 種類がある。

\section{観察ひえ度注}

ラス型双晶 $>$ 半ラス型双晶 $>\mathrm{Y}$ 型双晶 $>\mathrm{L}$ 型双晶 の順である。これらの総計は, 多い場合には, 単結晶の 数\%の割合に達する。1枚の板状晶法少なく，ほとえど の結晶にらせえ生長が見られる。

\section{2 ラス型双晶}

Fig. 2 にラス型双晶の写真を示す。結晶の一端は凸角 部, 他端は凹角部上なっている。凸角部に近いほど結晶 の幅が狭い，中央部の幅が共存する単結晶の幅にほぼ等 しい。らせえ生長が凹角部に近い方に見られ，凹角部で 結晶は二重になっている。結晶の側面をたどって行く と，らせん生長の中心に収れえする。らせえ生長の中心 は形態上の対称面にある場合が多い。ひだは対称面の両 側に対称的にある。中心に表面構造の粗な部分があり， その輪部は外形々相似形である。

Fig. 3 にラス型双晶の電子線回折図を示した。面間隔 の測定から，強い10 個の反射は (101) 面，(101) 面およ び (200) 面の反射である。観測された反射と逆格子との 関係を Fig. 4 に示した。これは(101)面の反射を共有し て, 二つの単結晶の回折図が重なっていることを示して いる。したがって, ラ大型の双晶では (101) 面が双晶面 である。ラス型双晶では, 凸角部の方が幅が狭くなって おり, 長い边は (101) 面注対して約 $5^{\circ}$ 傾いている。こ れは前報22で報告した平行四辺形の単結晶で, 結晶の両 端の幅が中央部の幅よりやや狭いことと対応するもので 西り，(101)面と(100)面よりなる鈍角部の成長が鋭角部

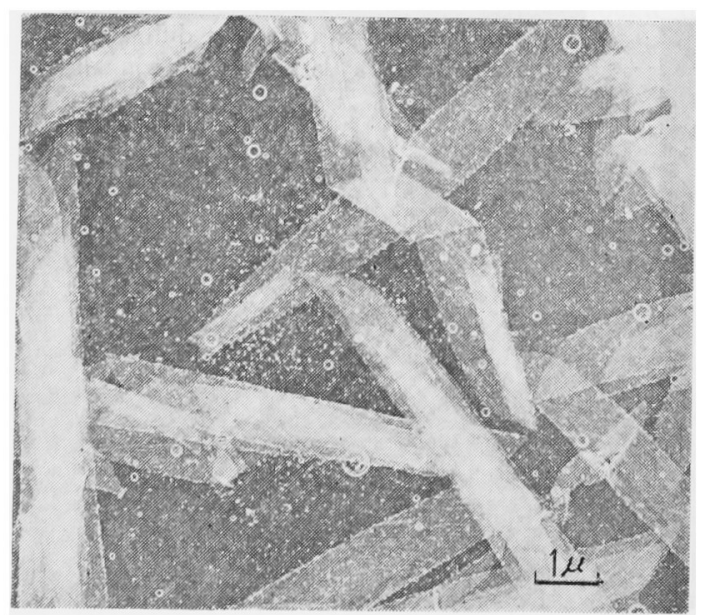

Fig. 5. Electron micrograph of partially lath-shaped twins of PVA.
の成長より遅れるために生ずる現象と考えられる。な お，ひだの方向は (301) 面に平行である。

\section{3 半ラス型双晶}

Fig. 5 および 6 に半ラス型双晶の観察例を示す。一 つの結晶の半分がラス型双晶であり，他の半分㹥平行四 辺形の板状晶である。観察されるほとんどのものは，凹 角部を有する半ラス型双晶であるが，Fig. 5 に見られる ように，凸角部を持った半ラス型双晶も存在する。双晶 面でらせん生長が起こっており, 凹角部や凸角部で結晶 が二重になっている場合が多い。平行四辺形部分の幅に 比べて, 凹角部の幅は広く, 凸角部の幅は狭い。(101) 面と（100）面よりなる鋭角部で生長が促進され，鈍角部 で遅れるためとと考えられる。Fig. 5 および 6 はシャ ドーイングをしないで撮影した写真である。中央部にみ られる外形と相似形の粗な表面構造を示す部分は外部よ り電子線の通過量が少なく，少し厚いことがわかる。

半ラス型双晶の制限視野電子線回折は平行四辺形部分 とラス型部分に分けて行なった。平行四辺形部分の回折 図は, すでに報告した単結晶の電子線回折図と一致し, ラス型部分の回折図は Fig. 3 で示したラス型双晶の電 子線回折図と一致する。したがって，半ラス型双晶もラ ス型部分は (101) 面の双晶である。Fig. 7 は Fig. 6 に 示した結晶の (101) 反射を用いた暗視野像である。写真 中に矢印で示した所で, 半ラス型双晶の一部が結像して いない。双晶境界が形態上の対称面にあることを示して いる。ラス型部分と平行四辺形部分の境界は長い辺にほ ぼ垂直である。これは半ラス型双晶の生長に伴って生じ た境界と考台られ双晶境界とい方る。

\section{$3.4 Y$ 型双晶}

Fig. 8 に Y 型双晶を示す。凹角部の二つの開き角の

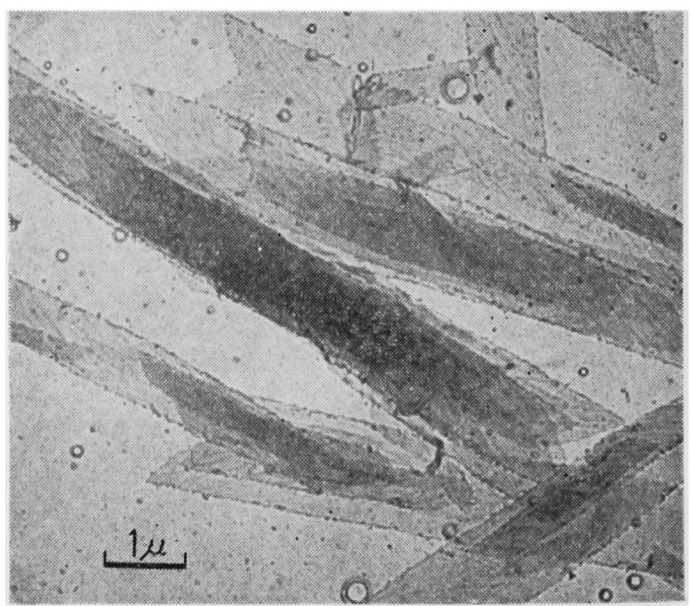

Fig. 6. Electron micrograph of lath-shaped and partially lath-shaped twins of PVA. 


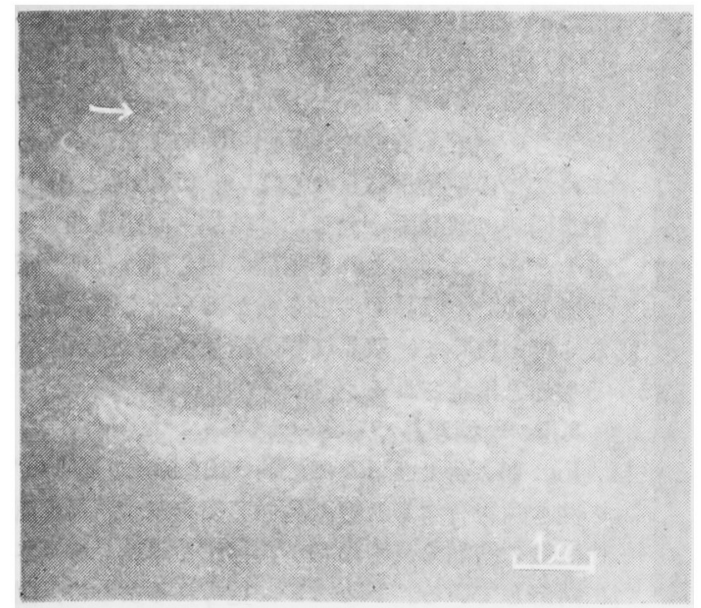

Electrons scattered into a $(10 \overrightarrow{1})$ reflection are imaged in this micrograph. The arrow indicates that a portion of a partially lath-shaped twin is dark.

Fig. 7. Dark field electron micrograph of lath-shaped and partially lath-shaped twins shown in Fig. 6 .

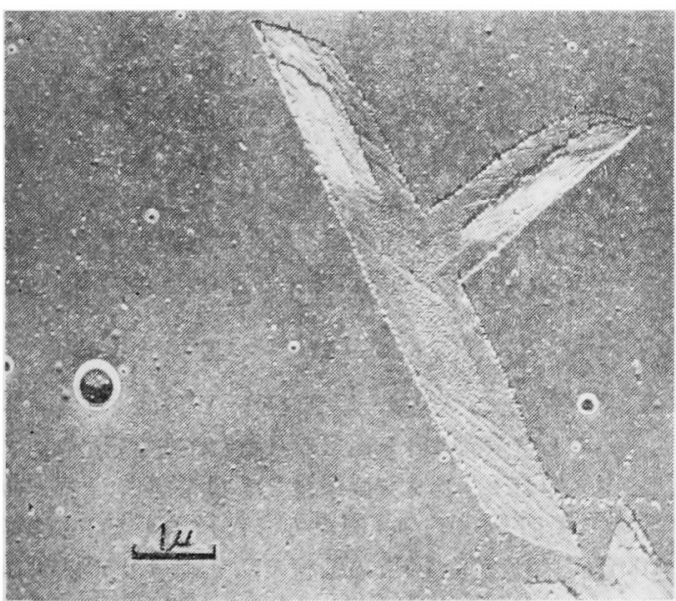

Fig. 8. Electron micrograph of a Y-shaped twin of PVA.

一方は約 $75^{\circ}$, 他方は約 $110^{\circ}$ である。結晶の先端に近 いほど幅が少し狭くなっており，両方の開き角の合計は $180^{\circ}$ より大きい場合が多い。中心部には表面の粗な部 分が存在し，その輸郭は結晶の外形と相似形である。明 りようならせん生長が観察される。結晶の周辺部には粒 子が付着している。ひだの模様から対称面の交点は結晶 の中心にあることが認められる。これ洁晶の成長が中 心から始まり, 結晶化開始の核に双晶発生の因子が存在 することを示唆するものである。

Fig. 8 に示した $\mathrm{Y}$ 型双晶の中央部の制限視野電子線

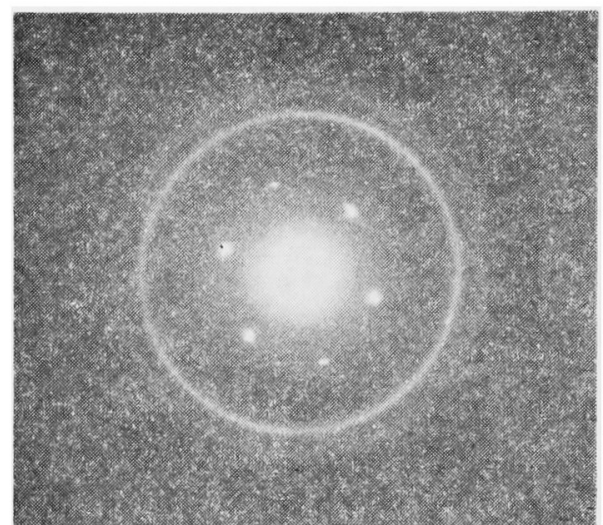

Rings are diffraction pattern from palladium.

Fig. 9. Selected-area electron diffraction pattern from a Y-shaped twin shown in Fig. 8.

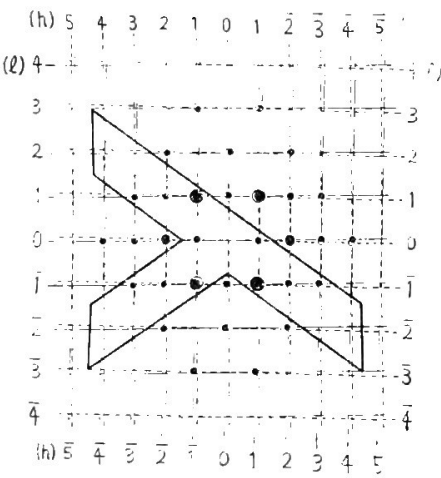

Dots and open circles represent the observed position of reflections. Thick lines show the external form of a $\mathrm{Y}$-shaped twin.

Fig. 10. Reciprocal lattice and indices of reflections.

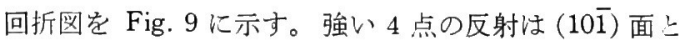
(101) 面の反射であり，二つの反射は近接して対になっ ている。そのほかに, (001)面, (002)面, (100)面および (200) 面の反射が観測される。それらの反射と逆格子と の闒係を Fig. 10 に示した。(h00) 面および (00l) 面の 反射がほぼ重なっていることおよび結晶の形態かり，一 応, (100)面と(001)面の両面が双晶面と考えられる。Y 型双晶の回折像で， $(h 00)$ 面と $(00 l)$ 面の反射が全く重 なっている場合もある。Y型双晶をカーボン支持膜上で 乾懆するさいに，枝分れしている結晶の位置が变わりや すいことを示している。(100)面, および(001)面は PVA の結晶の中で $(10 \overline{1})$ 面, および(101)面に次いで原子密度 の高い面であるので, 両面とも双晶面になりうると考党 られる。電子顕微鏡像と回折像の対応から, 約 $110^{\circ}$ 》 開き角を持った凹角部にある双晶面が (100) 面であり， 


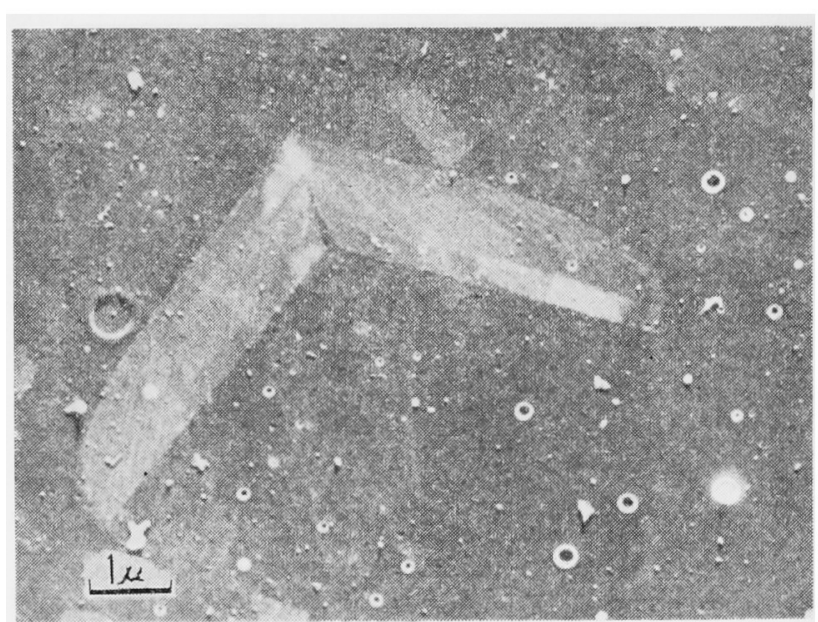

Fig. 11. Electron micrograph of a L-shaped twin of PVA.

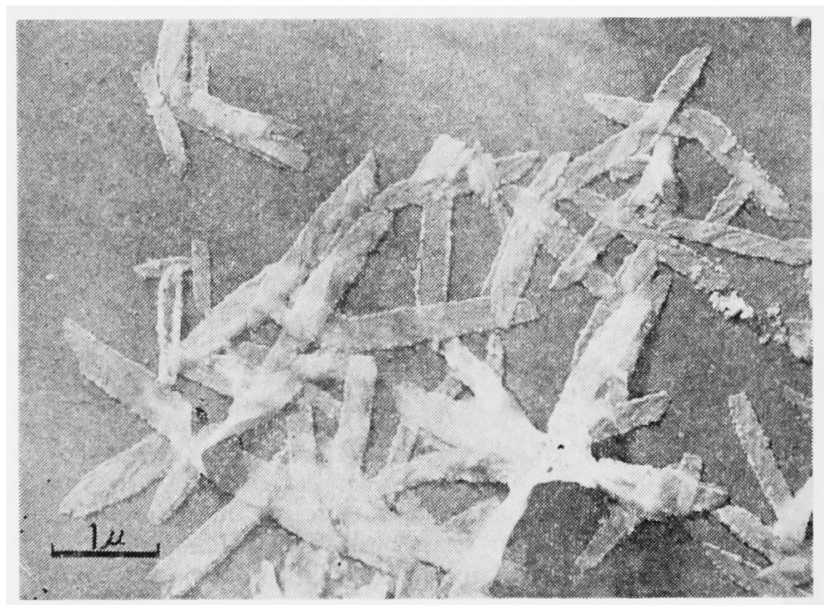

Fig. 12. Electron micrograph of single crystals and Lshaped twins of PVA.

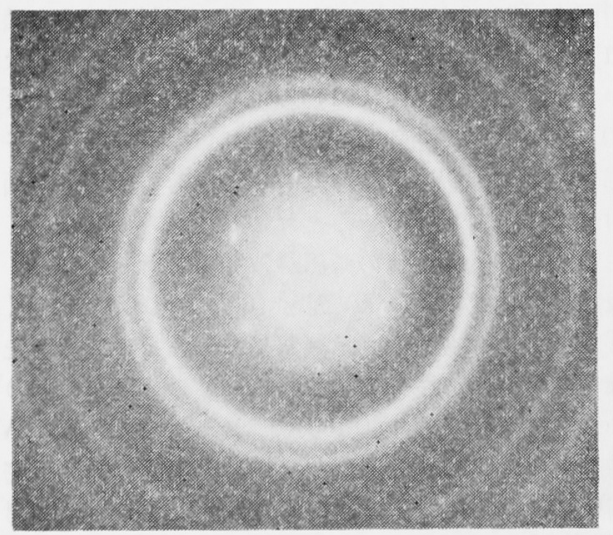

Fig. 13. Selected-area electron diffraction pattern from a L-shaped twin shown in Fig. 11.
約 $75^{\circ}$ の開き角を持った凹角部にある双晶面が (001) 面である。二つの双晶面は結晶の中心で合 っている。PVAの格子定数で, $\beta$ は $90^{\circ}$ より少 し大きい角であるので, Fig. 10 にみられるよう に, 二つの逆格子は重ならない。(100)面と(001) 面が同時に双晶面となるには結晶平面が彎曲する 必要がある。観察される結晶の中心部はほほ平板 であるので，双晶面のどちらかは完全な双晶面と なっていなくて，双晶境界の結晶構造は乱れてい るものと推定される。

\subsection{L 型双晶}

Fig. 11，および 12 に, 約 $110^{\circ}$ および約 $140^{\circ}$ の開き角を有するL型双晶の写真を示す。対称面 の両側の結晶の長さの和が共存する単結晶の長さ に対応している。Fig. 11 に見られるように, 開 き角約 $110^{\circ} の \mathrm{~L}$ 型双晶の対称面はへき開しやす w。

Fig. 11 に示す開き角約 $110^{\circ}$ の L 型双晶の電 子線回折図を Fig. 13 亿示す。(101)面, (101面), (200) 面および (002) 面の反射が観測される。 Fig. 9 に示した Y 型双晶の回折図に類似してい る。 Y 型双晶の場合には二つの対称面があるが， L 型双晶では一つである。(200) 反射を一対で共 有しているので，(100) 面の双晶であることが結 論される。開き角約 $140^{\circ}$ の双晶については観察 例が少なく電子線回折図が得られていない。しか し，Fig. 12 に見られるように形態とひだの模様 から(101)面が双晶面であると考えられる1)。

\section{4. 結言}

PVA のラス型, 半ラス型, $\mathrm{Y}$ 型および 2 種類 の L 型双晶の計 5 種類の双晶の存在を認めた。う ス型および半ラス型双晶では (101) 面, Y 型双晶 では (100)面と(001)面, 開き角約 $110^{\circ}$ の L 型双晶では (100)面, 開き角約 $140^{\circ}$ の 上型双晶では (101) 面が双晶 面である。双晶面が結晶の中心にあり，その両側の対称 性がよい場合が多い。PVA の成長双晶では, 結晶化の ときに双晶が発生しやすいことを示している。

付記：ご指導をいただいた当社研究所長松本昌一 博士に深く感謝する。また, 実験に協力された滥津 彰 氏に感謝する。なお, 本研究は日化 17 年会 (1964)で発 表した。

\section{文献}

1) K. Tsuboi, T. Mochizuki: J. Polymer Sci., B1, 531 (1963)

2）望月隆仁，郸井 清：高分子， 14，329 (1965), 高化 23, 636 (1966) 
3) K. Khoury, F. J. Padden, Jr.: J. Polymer Sci., 47, 455 (1960)

4) R. D. Burbank: Bell System Tech. J., 39, 1627 (1960)
5) 平井西夫, 安井武四, 藤田三郎, 山下裕彦: 高化, 20, 1413 (1963)

6) R. St. J. Manley: J. Polymer Sci., A2, 4503 (1964)

\title{
Studies on Single Crystals of Polyvinyl Alcohol
}

\section{Twins of Polyvinyl Alcohol}

\author{
By Kiyoshi Tsuboi* and Takani Mochizuki*
}

\begin{abstract}
Parallelogrammic lamellar crystals represent the most characteristic habit of polyvinyl alcohol crystallized from dilute solutions. In addition, however, the crystals are observed which differ from the parallelogrammic in shape such as lath-shaped, partially lath-shaped, Y-shaped and Lshaped lamellae. Measurements of the diffraction patterns of the lath-shaped and the partially lath-shaped lamellae show that the patterns arise from the superposition of the diffraction patterns given by two monoclinic lattices of the type observed for the parallelogrammic crystal and that those are the (101) reflection twins. The diffraction spots of the Y-shaped lamella nearly correspond to the constructed pattern of the reciprocal lattices of the (100) and the (001) reflection twins. It is confirmed that the composition plane having the re-entrant angle of $110^{\circ}$ is the (100) twinned plane and that having re-entrant angle of $75^{\circ}$ is the (001) twinned plane. In the Lshaped lamella, two kinds of lamellae with an angle of about $110^{\circ}$ or $140^{\circ}$ were observed. From the diffraction pattern and the shape of the crystal, it is concluded that the L-shaped lamella with an angle of about $110^{\circ}$ is the (100) reflection twin and that the L-shaped lamella with an angle of about $140^{\circ}$ is the $(10 \overline{1})$ reflection twin. The composition plane is almost in the middle of the crystal. Corrugations intersected at the composition plane are observed. The granular parts having a similar figure to the external form are observed in the middle of the crystal.
\end{abstract}

\section{第 3 報ポリビニルアルコール単結晶の電子線回折}

（1966 年 1 月 14 日受理）

$$
\text { 坪井 清**。望月隆仁** }
$$

\footnotetext{
要 旨 ポリビニルアルニール(PVA) 単結晶の結晶組織の電子線照射による変化を調べた。ま た，面間隔変化ふふ西方り起こっていない場合の回折像から格子定数を求めた。PVA 単結晶はポリ エチレン単結晶に比べて，電子線照射による変化をより受けやすい。(101)面は(101)面よりも面間 隔変化の割合が大きく, 長時間の照射で両者の面間隔は等しくなる。電子線回折写真から格子定数 を計測する場合飞流, 回折像をすばやく撮影する必要があることを認めた。この点に注意して求め たPVA の結晶の格子定数は, $a=7.81 \pm 0.02 \AA, c=5.43 \pm 0.01 \AA, \beta=91^{\circ} 30^{\prime} \pm 15^{\prime}$ である。単結 晶では, 従来のPVA 試料比べて $c$ 軸長分やや小さい。
}

\section{1. 緒言}

さきに，著者らはポリビニレアルコール(PVA) 単結 晶の電子線回折を行ない，結晶面を明ら加にした ${ }^{1), 2) 。 ~}$ 通常, 高分子物質の電子線回折像注電子線の連続照射汇 よって容易に消失するる。ここれ電子線の照射によって 単絬晶が非晶化するため之考兵られる。坂奥4) (電子線
照射によるポリエチレン単結晶の結晶構造の变化を研究 し，面間隔が電子線照射によって增大し，非晶化に至る こと定報告している。電子線回折図から格子定数求め る場合, かかる面間隔变化には留意する必要がある。

本報で注, PVA の単結晶の反射の面間隔が電子線照 射によってどのように変化するか穵調べ，面間隔変化が あまり起こっていない場合の回折像から格子定数を求め

* Research Laboratory, Kurashiki Rayon Co., Ltd. (Kurashiki, Okayama)

**倉数レイヨン株式会社研究所（岡山県倉敷市酒津1621） 